\title{
Nerve Growth Factor Antiserum Induces Axotomy-Like Changes in Neuropeptide Expression in Intact Sympathetic and Sensory Neurons
}

\author{
Annette M. Shadiack, Yi Sun, and Richard E. Zigmond \\ Department of Neurosciences, School of Medicine, Case Western Reserve University, Cleveland, Ohio 44106-4975
}

Axonal transection of adult sympathetic and sensory neurons leads to a decrease in their content of target-derived nerve growth factor (NGF) and to dramatic changes in the expression of several neuropeptides and enzymes involved in transmitter biosynthesis. For example, axotomy of sympathetic neurons in the superior cervical ganglion (SCG) dramatically increases levels of galanin, vasoactive intestinal peptide (VIP), and substance $P$ and their respective mRNAs and decreases mRNA levels for neuropeptide $Y$ (NPY) and tyrosine hydroxylase (TH). Axotomy of sensory neurons in lumbar dorsal root ganglia (DRG) increases protein and mRNA levels for galanin and VIP and decreases levels for substance $P$ and calcitonin generelated peptide (CGRP). To assess whether reduction in the availability of endogenous NGF might play an important role in triggering these changes, we injected nonoperated animals with an antiserum against NGF ( $\alpha$ NGF). $\alpha$ NGF increased levels of peptide and mRNA for galanin and VIP in neurons in both the SCG and DRG. NPY protein and mRNA were decreased in the SCG, but levels of TH protein and mRNA remained unchanged. In sensory neurons the levels of SP and CGRP protein decreased after $\alpha$ NGF treatment. These data suggest that the reduction in levels of NGF in sympathetic and sensory neurons after axotomy is partly responsible for the subsequent changes in neuropeptide expression. Thus, the peptide phenotype of these axotomized neurons is regulated both by the induction of an "injury factor," leukemia inhibitory factor, as shown previously, and by the reduction in a target-derived growth factor.

Key words: axotomy; calcitonin gene-related peptide; dorsal root ganglion; galanin; leukemia inhibitory factor; NGF; neuropeptide Y; sensory neurons; substance $P$; superior cervical ganglion; sympathetic neurons; tyrosine hydroxylase; vasoactive intestinal peptide
Axotomy of sympathetic and sensory neurons leads to a decrease in the level of a number of proteins associated with synaptic transmission and of their respective mRNAs. For example, in sympathetic neurons in the superior cervical ganglion (SCG) the levels of RNA for tyrosine hydroxylase (TH), neuropeptide $\mathrm{Y}$ (NPY), and several nicotinic receptor subunits decrease (for review, see Zigmond, 1997). In sensory neurons in the dorsal root ganglion (DRG) levels of mRNA for substance $P$ and calcitonin gene-related peptide (CGRP) decrease (Zigmond, 1997). At the same time, in both types of neurons the levels of mRNA for cytoskeletal proteins, such as certain tubulin isoforms, and growth-associated proteins, such as GAP-43, increase (Mathew and Miller, 1990; Wong and Oblinger, 1991; Liabotis and Schreyer, 1995, Zigmond et al., 1996). These changes appear to be adaptations to a situation in which the neurons are no longer engaged in synaptic transmission with their targets and are, instead, involved in regeneration (Hårkönen, 1964; Hebb and Silver, 1966; Cheah and Geffen, 1973).

Axotomized peripheral neurons also change the neuropeptides

\footnotetext{
Received Jan. 18, 1999; revised Oct. 10, 2000; accepted Oct. 13, 2000.

This research was supported by National Institutes of Health Research Grants NS 12651 and NS 17512. A.M.S. was supported by National Institutes of Health Training Grant NS 07118.

Correspondence should be addressed to Dr. Richard E. Zigmond, Department of Neurosciences, Case Western Reserve University, 10900 Euclid Avenue, Cleveland, OH 44106-4975. E-mail: rez@po.cwru.edu.

Dr. Shadiack's present address: Palatin Technologies, 175 May Street, Suite 500, Edison, NJ 08837.

Dr. Sun's present address: Department of Neurology, Division of Neuroscience, Children's Hospital and Department of Neurobiology, Harvard Medical School, Boston, MA 02115.

Copyright (C) 2001 Society for Neuroscience 0270-6474/01/210363-09\$15.00/0
}

that they express. The particular peptides that are altered can vary in different types of neurons. For example, after axotomy, sympathetic neurons begin to express substance $\mathrm{P}$ and decrease expressing neuropeptide $\mathrm{Y}$, whereas sensory neurons do the opposite (Zigmond, 1997). Two peptides, however, vasoactive intestinal peptide (VIP) and galanin, are induced in both axotomized sympathetic and sensory neurons (Zigmond, 1997). Recent data suggest that these two peptides promote the survival of peripheral neurons and/or axonal outgrowth (Tanaka and Koike, 1994; Klimaschewski et al., 1995; Rayan et al., 1995; Holmes et al., 1997).

Two consequences of axotomy have been implicated as triggers for these changes in peptide phenotype. One is the induction of leukemia inhibitory factor (LIF; Banner and Patterson, 1994; Curtis et al., 1994; Sun et al., 1994, 1996). Studies with $\mathrm{LIF}^{-/-}$ mice have demonstrated that, in the absence of LIF, there is a large reduction in the magnitude of both the axotomy-induced increases in galanin and VIP in the SCG (Rao et al., 1993a) and a smaller reduction of the decreases in TH and NPY (Sun and Zigmond, 1996a). In addition, a smaller increase in galanin was seen after axotomy in DRG from $\mathrm{LIF}^{-1-}$ than from wild-type mice (Corness et al., 1996; Sun and Zigmond, 1996b).

A second consequence of axotomy is the loss of target-derived factors such as NGF. Although adult sympathetic and sensory neurons survive for weeks in the absence of NGF, the loss of NGF does produce phenotypic changes in these neurons (Zhou and Rush, 1996; Ruit et al., 1990). The idea that the reduction in endogenous NGF might be involved in triggering certain changes in neuropeptide phenotype after axotomy is suggested by the 

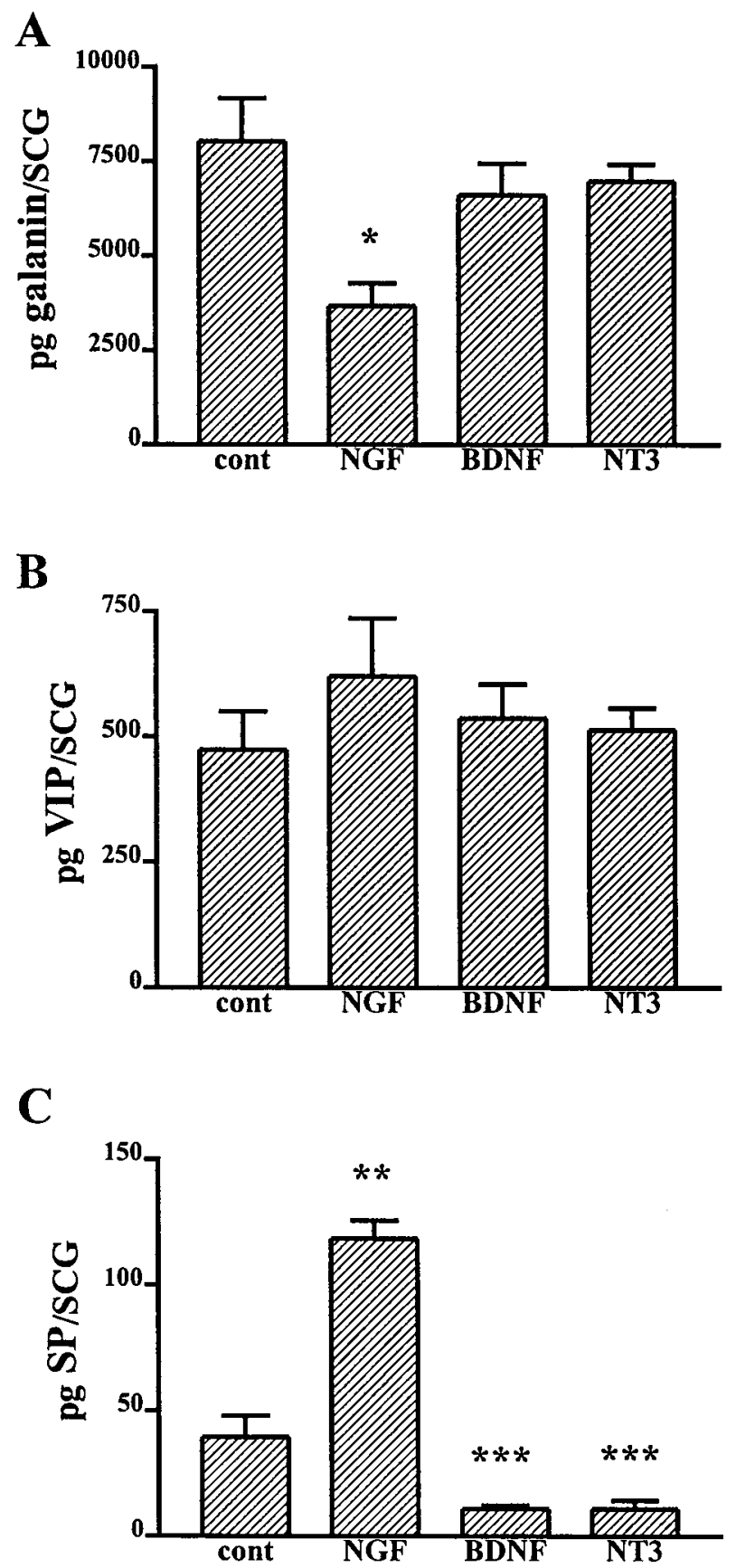

Figure 1. Effects of neurotrophins on neuropeptide levels in SCG in organ culture. Adult SCG were cultured in F12 medium alone (cont) or in the presence of $50 \mathrm{ng} / \mathrm{ml}$ of NGF, BDNF, or NT3. After $48 \mathrm{hr}$ in culture the individual SCG were analyzed by radioimmunoassay for galanin-IR $(A)$, VIP-IR $(B)$, and SP-IR $(C)$. Data are the means of six ganglia \pm SEM. Levels of all three of these neuropeptides are barely detectable in ganglia before explantation (Hyatt-Sachs et al., 1993; Rao et al., 1993b; Schreiber et al., 1994). ${ }^{*} p<0.009,{ }^{* *} p<0.004$, and ${ }^{* * *} p<0.02$ versus corresponding control.

finding that exogenous NGF can inhibit a number of these changes (Sun et al., 1993; Sun and Zigmond, 1995; Verge et al., 1995). Direct evidence that reduction of endogenous NGF can trigger changes in peptide expression similar to those seen after axotomy, however, is lacking. We approached this question by examining the effects of an antiserum to NGF on neuropeptide expression in intact animals (Zigmond et al., 1995).

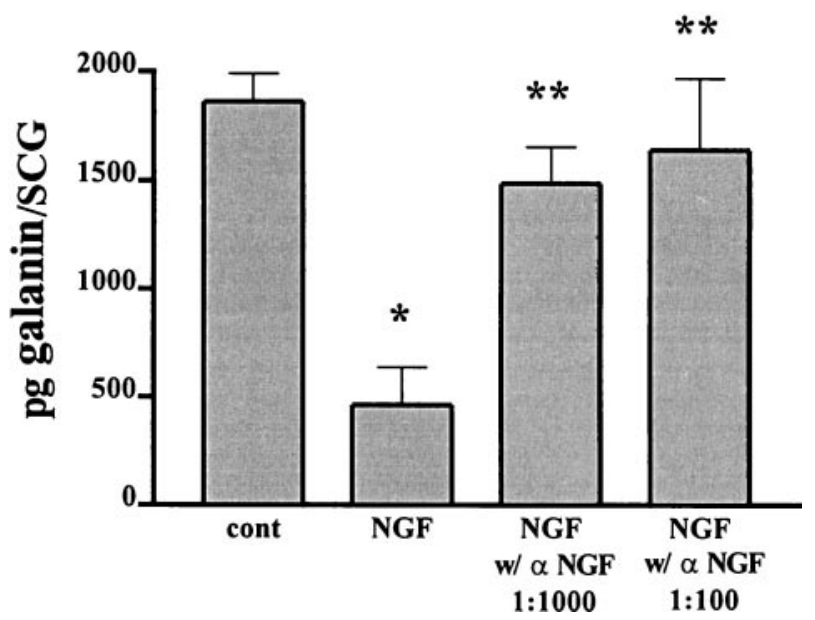

Figure 2. $\alpha$ NGF reverses the inhibitory effect of NGF on galanin-IR. Adult SCG were cultured for $48 \mathrm{hr}$ in F12 medium alone or in the presence of $50 \mathrm{ng} / \mathrm{ml}$ NGF. To some of the NGF-treated cultures we also added different concentrations of an antiserum to NGF. Galanin-IR was assayed by radioimmunoassay in individual SCG. Data are the means of six ganglia $\pm \mathrm{SEM} ;{ }^{*} p<0.004$ versus control and ${ }^{*} p<0.02$ versus NGF.

\section{MATERIALS AND METHODS}

Adult male Sprague Dawley rats (200-250 gm) were purchased from Zivic-Miller (Zelienople, PA) and were used in all of the experiments described below.

Organ culture experiments. Rats were killed with $\mathrm{CO}_{2}$ vapors, and their SCG were removed and desheathed. SCG were cultured for $48 \mathrm{hr}$ in F12 chemically defined medium (Life Technologies, Grand Island, NY) either alone or containing $50 \mathrm{ng} / \mathrm{ml}$ of one of the following neurotrophins: $\beta$-NGF (Austral Biologicals, San Ramon, CA), brain-derived neurotrophic factor (BDNF; a gift from Dr. T. Large, Case Western Reserve University, Cleveland, OH), or neurotrophin-3 (NT3; also a gift from Dr. Large). In other experiments the SCG were cultured in F12-defined medium alone, $50 \mathrm{ng} / \mathrm{ml} \mathrm{NGF}$ alone, or $50 \mathrm{ng} / \mathrm{ml} \mathrm{NGF}$ and anti-NGF antiserum at a concentration of 1:1000 or 1:100 ( $\alpha$ NGF; obtained from Dr. J. Diamond, McMaster University, Ontario, Canada). The antiserum was raised in sheep by using $2.5 \mathrm{~S}$ NGF purified from male mouse salivary glands (Gloster and Diamond, 1995). At the end of the culture period the SCG were harvested, quickly frozen on dry ice, and stored at $-80^{\circ} \mathrm{C}$ until they were assayed.

$N G F$ treatment in vivo. Rats were anesthetized by intraperitoneal injection with a mixture of Rompun (xylazine, $0.24 \mathrm{mg} / 100 \mathrm{gm}$ ) and Ketaset (ketamine-HCl, $108 \mathrm{mg} / 100 \mathrm{gm}$ ). The drugs were purchased from W. A. Butler (Warren, OH). Neurons in the SCG were axotomized by the transection of the two major postganglionic trunks, the internal and external carotid nerves, within $2 \mathrm{~mm}$ of where they exit the ganglion. A 14 d slow-release pellet from Innovative Research of America (Sarasota, FL) containing $2.5 \mu \mathrm{g} /$ pellet of NGF was applied to the partially desheathed SCG immediately after the postganglionic trunks were cut. Placebo pellets lacking NGF served as controls. At 2, 7, and $14 \mathrm{~d}$ after surgery the SCG were dissected, frozen on dry ice, and stored at $-80^{\circ} \mathrm{C}$ until they were assayed.

$\alpha N G F$ treatment in vivo. Daily, the rats were injected intraperitoneally with $0.5 \mathrm{cc}$ of either sheep $\alpha$ NGF or normal sheep serum (NSS; Sigma, St. Louis, MO). Animals were treated for 3, 7, or $14 \mathrm{~d}$ and killed $24 \mathrm{hr}$ after their final injection. SCG and L4 and L5 DRG were removed, quickly frozen on dry ice, and stored at $-80^{\circ} \mathrm{C}$ until they were assayed.

Radioimmunoassay (RIA). SCG were assayed for galanin-, VIP-, and NPY-like immunoreactivity (IR), and L5 DRG were assayed for galanin-, VIP-, and SP-IR by methods described previously (Zigmond et al., 1992; Hyatt-Sachs et al., 1993; Rao et al., 1993b; Schreiber et al., 1994;). Briefly, ganglia were boiled for $20 \mathrm{~min}$ in $2 \mathrm{~N}$ acetic acid, vortexed, and centrifuged for $15 \mathrm{~min}$. The supernatants were lyophilized and reconstituted in assay buffer and assayed for their content of peptide-IR. CGRP was assayed with an RIA kit purchased from Peninsula (Belmont, CA). RIA data are expressed as the mean picogram of peptide-IR/ ganglion \pm SEM, with $n=6$ per group. Statistical analyses of the means were made with an unpaired Student's $t$ test. 

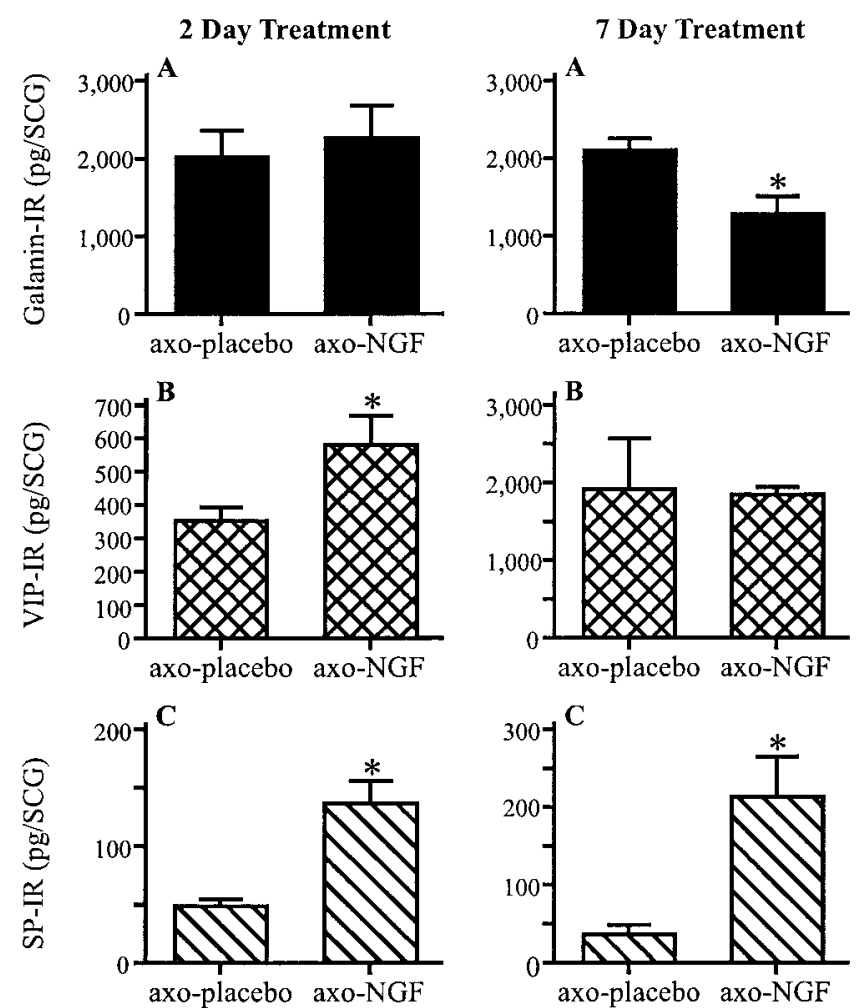

Northern blot analysis. RNA from two SCG or three DRG was extracted via RNAzol B (Tel-Test, Friendswood, TX) as previously described (Sun and Zigmond, 1996a). Samples were run on a 1.2\% agarose gel and transferred to a nylon membrane. Membranes containing SCG samples were hybridized with ${ }^{32} \mathrm{P}$-labeled cDNA probes to VIP (from Dr. J. Stephen Fink, Massachusetts General Hospital; Segerson et al., 1989), NPY (from Dr. S. L. Sabol, National Institutes of Health, Bethesda, MD; Higuchi et al., 1988), TH (from Dr. D. Chikaraishi, Duke University, Durham, NC; Grima et al., 1985; Harrington et al., 1987), and GAPDH (from Dr. J. M. Blanchard, Université Montpellier II, Montpellier, France; Fort et al., 1985) and an oligonucleotide probe to rat galanin (39-mer containing the sequence between 239 and 277). Membranes containing DRG samples were hybridized with ${ }^{32} \mathrm{P}$-labeled cDNA probes to VIP, $\beta$-preprotachykinin ( $\beta$-PPT; from Dr. J. E. Krause, Washington University, St. Louis, MO; Krause et al., 1987), $\beta$-CGRP (from Dr. S. G. Amara, Vollum Institute, Portland, OR; Amara et al., 1985), and GAPDH and the oligonucleotide probe to galanin. Labeled membranes were exposed to a PhosphorImager screen overnight and quantified on a PhosphorImager (Molecular Dynamics, Sunnyvale, CA). Data are expressed as the density of the mRNA band in question relative to the density of the GAPDH band in the same sample. In the case of the DRG samples in which there were three or more measurements per group, the means of different groups were compared by an unpaired Student's $t$ test.

\section{RESULTS}

\section{NGF alters neuropeptide expression in explant cultures of adult SCG}

Culturing adult SCG in defined medium triggers many changes in gene expression that also are seen in vivo after axotomy. For example, levels of VIP, galanin, and substance P are extremely low in intact ganglia in vivo, with most neurons containing no detectable peptide-IR; however, these three peptides are induced dramatically after explantation, as they are after axotomy (Zigmond et al., 1992; Sun et al., 1992, 1996; Schreiber et al., 1994). In most of the studies just cited, the medium that was used did not contain NGF. The addition of NGF $(50 \mathrm{ng} / \mathrm{ml})$ to $\mathrm{F} 12$ medium significantly affected the increases in neuropeptide levels seen
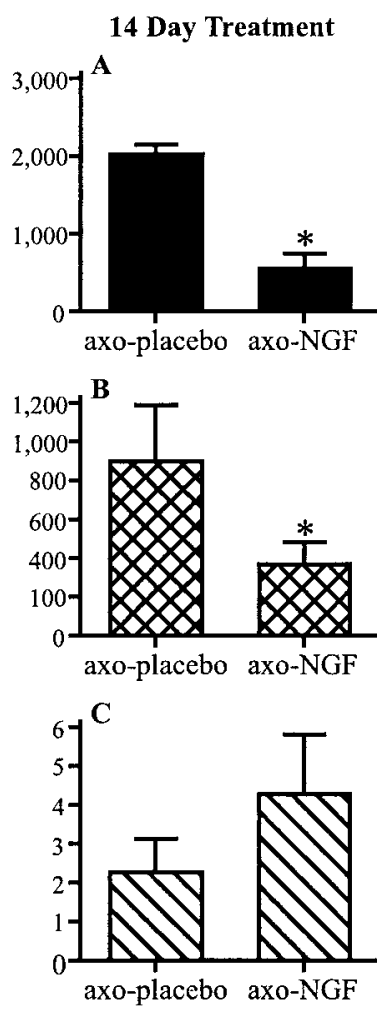

Figure 3. Effects of NGF on neuropeptide levels in SCG in vivo. The internal and external carotid nerves were transected, and the SCG were partially desheathed. Then an NGF or a placebo pellet was placed in contact with each desheathed ganglion. At 2, 7, or $14 \mathrm{~d}$ later the SCG were removed and assayed individually for galanin-IR $(A)$, VIP-IR $(B)$, and SP-IR $(C)$. The data represent the mean values \pm SEM of 11 ganglia (for the $2 \mathrm{~d}$ treatment group) or four ganglia (for the other two groups). ${ }^{*} p<0.05$ versus corresponding placebo. after $48 \mathrm{hr}$ in organ culture, inhibiting by $\sim 50-70 \%$ the level of galanin-IR, increasing by $\sim 250 \%$ the level of substance P-IR, and not significantly altering the level of VIP-IR (Figs. 1, 2). In concentration-response studies, $50 \%$ inhibition of galanin-IR was seen at a concentration of $10 \mathrm{ng} / \mathrm{ml}$ NGF (data not shown). To examine the specificity of this effect and to determine whether it might be mediated by the general low-affinity neurotrophin receptor, we compared the action of NGF with that of BDNF and NT3 (Fig. 1). At a concentration of $50 \mathrm{ng} / \mathrm{ml}$ neither BDNF nor NT3 affected the levels of galanin or VIP, although significant decreases in SP-IR were found (Fig. 1). To control for the possibility that at these somewhat high concentrations (i.e., 50 $\mathrm{ng} / \mathrm{ml}$ ) the NGF effect might be caused by a contaminant in the preparation rather than by NGF itself, we examined the ability of $\alpha$ NGF to block the inhibitory effects of NGF on galanin expression. The effect of NGF was blocked by $75-90 \%$ by $\alpha$ NGF (Fig. 2).

\section{Effects of exogenous NGF treatment on peptide expression in SCG in vivo after axotomy}

To insure that the inhibitory effect of NGF on galanin expression was not restricted to neurons in culture and to assess the longer term effect of treatment, we also administered NGF to axotomized neurons in the SCG in vivo. Immediately after transection of the two major postganglionic trunks of the SCG, the ganglion was partially desheathed, and a slow-release pellet containing NGF or a control pellet containing the matrix material alone was placed in contact with the ganglion. At 2, 7, and $14 \mathrm{~d}$ later the ganglia were assayed for galanin-, VIP-, and SP-IR. NGF inhibited the levels of galanin-IR in axotomized neurons at $7 \mathrm{~d}$ (by $\sim 40 \%$ ) and at $14 \mathrm{~d}$ (by $\sim 75 \%$; Fig. 3). In contrast, substance P-IR was increased $\sim 200 \%$ at $2 \mathrm{~d}$ and by $\sim 500 \%$ at $7 \mathrm{~d}$. The effect of in vivo administration of NGF on VIP-IR in axotomized SCG was more complex, with a $70 \%$ increase at $2 \mathrm{~d}$, no change at $7 \mathrm{~d}$, and a $74 \%$ decrease at $14 \mathrm{~d}$. 

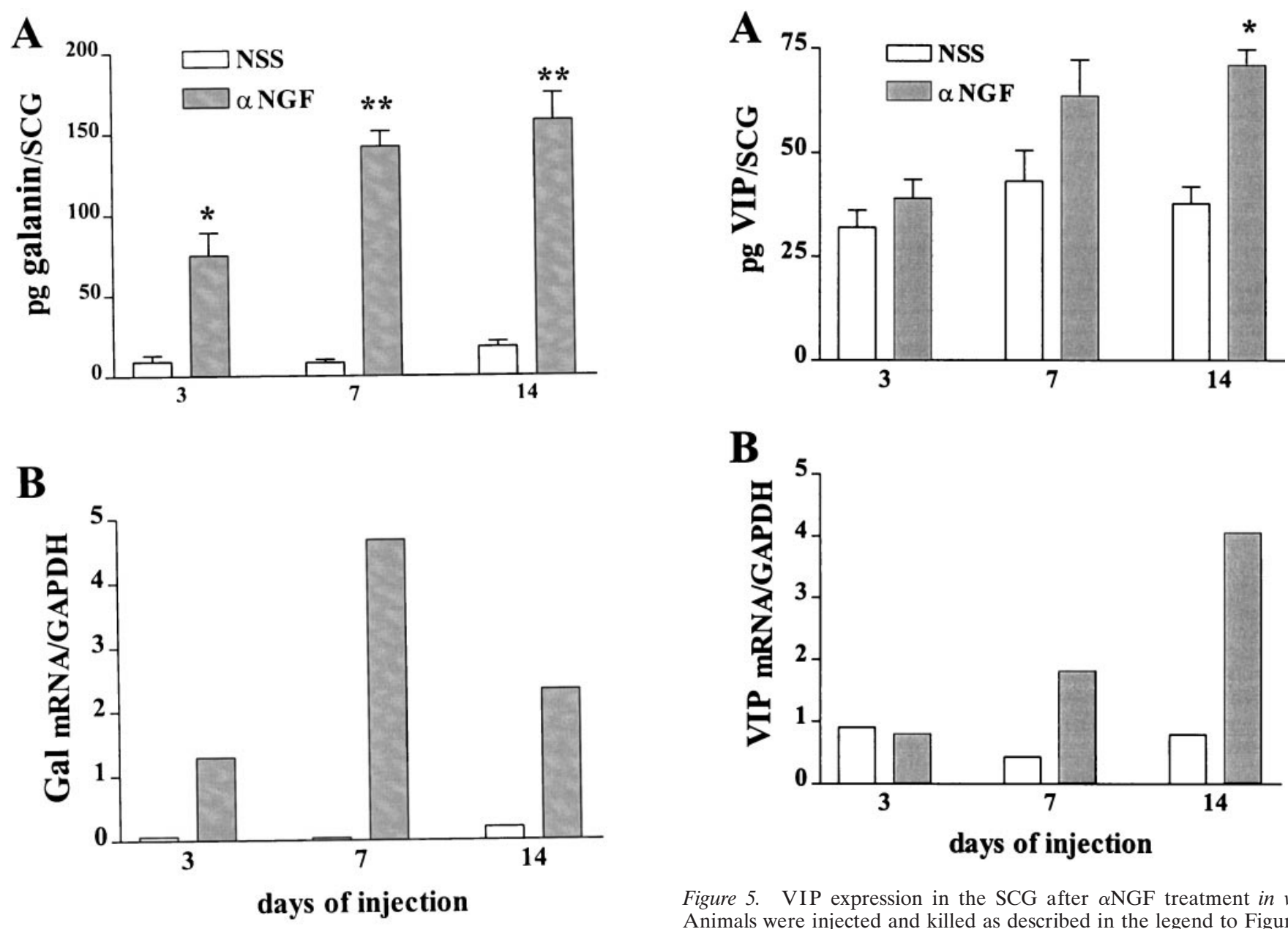

Figure 5. VIP expression in the SCG after $\alpha$ NGF treatment in vivo. Animals were injected and killed as described in the legend to Figure 4. $A$, Radioimmunoassay data for VIP-IR in SCG from $\alpha$ NGF- or NSSinjected rats. ${ }^{*} p<0.0001$ versus NSS at the same time point. $B$, Results of Northern blot analysis for VIP mRNA in SCG from $\alpha$ NGF- or NSS-injected rats.

\section{$\alpha$ NGF treatment increases the expression of galanin and VIP in SCG in vivo}

Because NGF is able to partially inhibit the increase in galanin levels caused by injury, we sought to determine whether endogenous NGF inhibits the expression of galanin in intact SCG neurons. Adult rats were treated with daily injections of $\alpha \mathrm{NGF}$ to reduce NGF availability to peripheral neurons in control (i.e., nonoperated) animals. At various times thereafter, peptide and mRNA levels in SCG were compared with those in ganglia from NSStreated animals. Levels of galanin-IR were significantly higher in SCG from $\alpha$ NGF-treated animals after only three daily injections of antiserum (Fig. 4A). These levels continued to increase with $7 \mathrm{~d}$ of treatment and remained high after $14 \mathrm{~d}$ of injections. These increases in galanin peptide levels were accompanied by an increase in the steady-state levels of galanin mRNA, with peak values seen after $7 \mathrm{~d}$ of antiserum treatment (Fig. 4B). When VIP expression was measured in the same $\mathrm{SCG}$, a significant increase in levels of VIP-IR occurred after $14 \mathrm{~d}$ of injection (Fig. $5 A$ ). An increase in steady-state levels of VIP mRNA also occurred after $\alpha$ NGF treatment (Fig. 5B).

$\alpha$ NGF treatment decreases the expression of NPY, but not TH, mRNA in SCG

Approximately $60 \%$ of the sympathetic neurons of the SCG contain NPY-IR, and nearly all contain TH-IR (Zigmond et al., illed $24 \mathrm{hr}$ after the last injection. $A$, Some SCG were assa for galanin-IR by radioimmunoassay. Data are the means of six ganglia \pm SEM; ${ }^{*} p<0.002$ and ${ }^{* *} p<0.0001$ versus NSS at the same time point. $B$, Other SCG were assayed for steady-state levels of galanin mRNA by Northern blot analysis. Data are expressed as a ratio to the level of GAPDH mRNA in each sample, and the mean values of two groups of two SCG each are shown. At the bottom of the figure a representative autoradiograph of the blot from this experiment is shown. The data presented in Figures 5-7 using probes for other mRNAs were obtained from the same blot. 

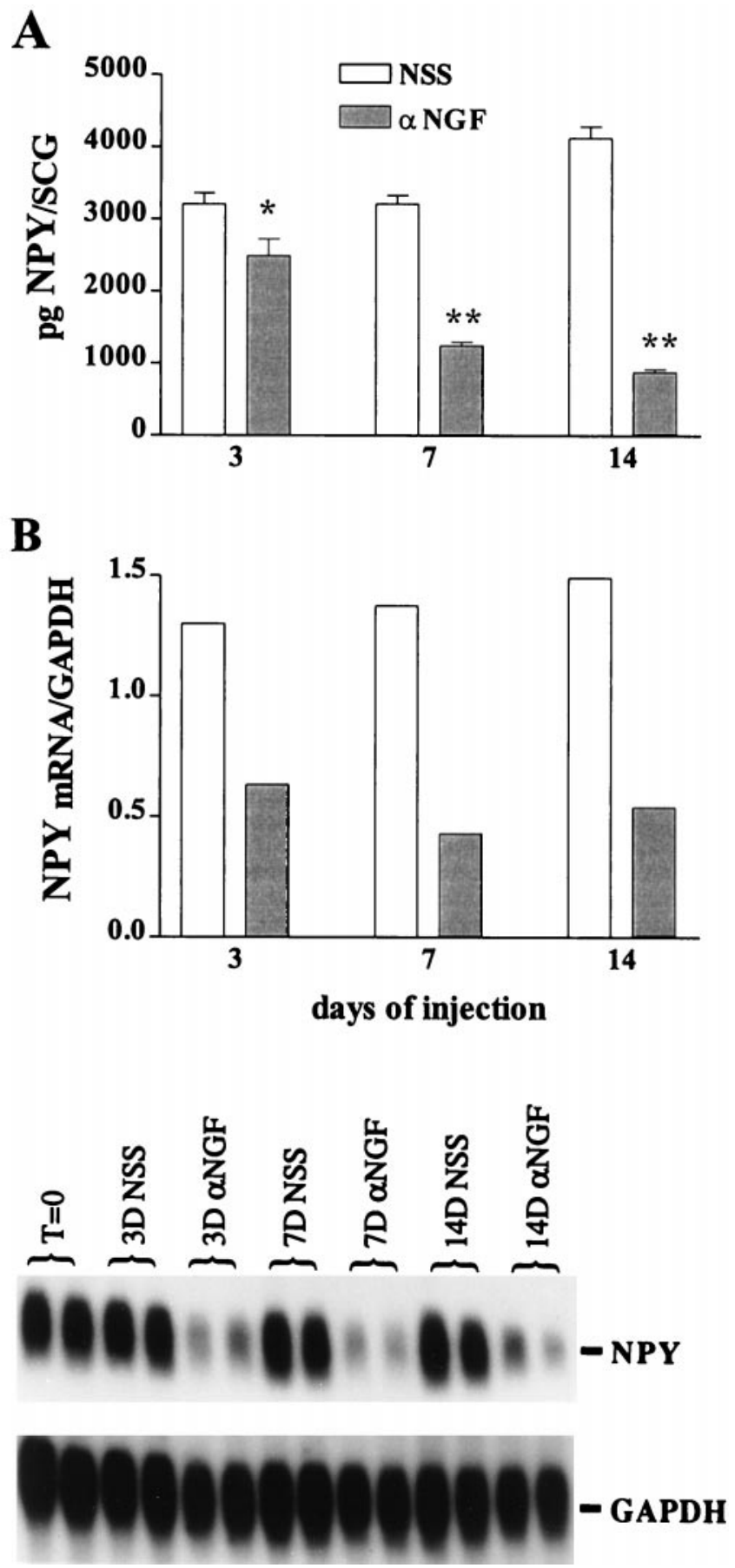

Figure 6. NPY expression in the SCG after $\alpha$ NGF treatment in vivo. Animals were injected and killed as described in the legend to Figure 4. $A$, Radioimmunoassay data for NPY-IR in SCG from $\alpha$ NGF- or NSSinjected rats. $* p<0.03$ and ${ }^{*} p<0.0001$ versus NSS at the same time point. $B$, Results of Northern blot analysis for NPY mRNA in SCG from $\alpha$ NGF- or NSS-injected rats. At the bottom of the figure an autoradiograph of a representative Northern blot is shown.

1996). After axotomy, levels of NPY mRNA decrease (Sun and Zigmond, 1996a), although peptide levels increase for the first few days (Zigmond et al., 1992). Immunohistochemical studies indicate that during this period there is an actual decrease in the number of immunoreactive neuronal cell bodies but a large increase in the number of immunoreactive processes (Kroesen et al., 1997), suggesting that the increased peptide results from

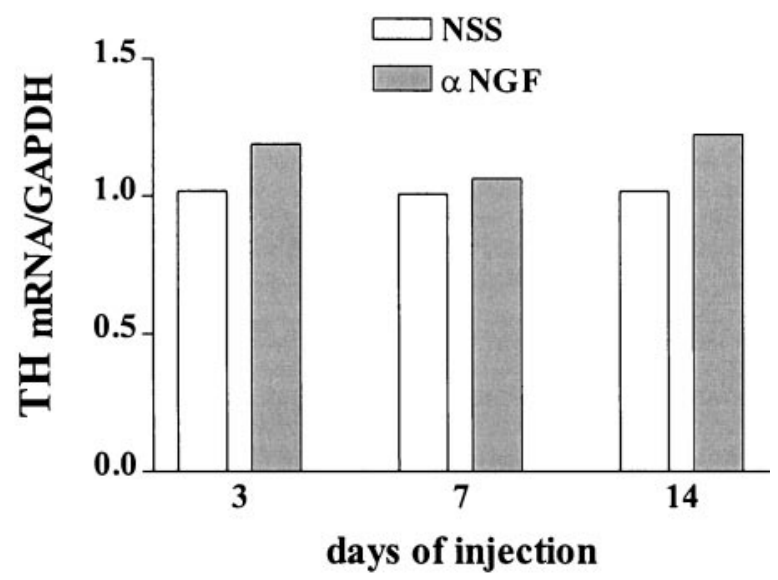

Figure 7. TH mRNA expression in the SCG after $\alpha$ NGF treatment in vivo. Animals were injected and killed as described in the legend to Figure 4. These data are the results of Northern blot analysis for TH mRNA in $\mathrm{SCG}$ from $\alpha \mathrm{NGF}$ - or NSS-injected rats.

peptide accumulation caused by blockade of axonal transport. After $\alpha$ NGF treatment the levels of both NPY peptide and NPY mRNA decreased as compared with levels in ganglia from NSStreated animals (Fig. 6A,B). A significant decrease in expression was seen after $3 \mathrm{~d}$ of injection, and larger decreases occurred after 7 and $14 \mathrm{~d}$.

Axotomy of sympathetic neurons causes a decrease in $\mathrm{TH}$ mRNA (Koo et al., 1988; Sun and Zigmond, 1996a) and in TH activity (Cheah and Geffen, 1973) (but see Hendry, 1976; Federoff et al., 1992). Treatment with $\alpha \mathrm{NGF}$, however, had no effect on the steady-state levels of TH mRNA (Fig. 7). Also, measurements of $\mathrm{TH}$ peptide by Western blot analysis showed no apparent change over $14 \mathrm{~d}$ of $\alpha \mathrm{NGF}$ treatment (data not shown).

\section{$\alpha$ NGF treatment increases the expression of galanin and VIP in DRG}

Neuropeptide levels also were examined in L4 and L5 DRG taken from the same animals for which the SCG had been assayed. In DRG the galanin peptide levels showed a transient increase with $\alpha \mathrm{NGF}$ treatment, whereas the steady-state levels of galanin mRNA showed a more sustained increase (Fig. $8 A, C$ ). This same treatment caused an increase in the levels of both VIP peptide and mRNA in the DRG (Fig. 8B,D).

\section{$\alpha$ NGF treatment decreases the levels of SP and CGRP peptide in DRG}

In the case of both SP and CGRP peptide levels, $\alpha$ NGF treatment for $7 \mathrm{~d}$ caused a decrease as compared with control treatment (Fig. 9A,B). After $14 \mathrm{~d}$ of treatment the peptide levels in the $\alpha$ NGF-treated DRG were still depressed; however, by this time point the peptide levels in the NSS-treated DRG were decreased also. Compared with the changes in peptide levels, there was a less substantial decrease in the steady-state levels of $\beta$-PPT mRNA and no measurable change in $\beta$-CGRP mRNA in ganglia from $\alpha$ NGF-treated animals (Fig. 9C,D).

\section{DISCUSSION}

\section{Decreased NGF: A trigger for increasing neuropeptide expression after axotomy}

Axotomy of sympathetic and sensory neurons results in a decrease in their content of NGF (Korsching and Thoenen, 1985a,b; Nagata et al., 1987; Zhou et al., 1994) and in the induction of LIF by associated non-neuronal cells (Banner and Patterson, 1994; 
Figure 8. Galanin and VIP expression in the DRG after $\alpha$ NGF treatment in vivo. Adult rats were treated with daily injections of $\alpha$ NGF or NSS and killed after 3, 7, or $14 \mathrm{~d}$. L5 DRG were assayed for galanin-IR $(A)$ and VIP $(B)$ by radioimmunoassay. The data are the means of six DRG \pm SEM. L4 and L5 DRG were assayed for steady-state levels of galanin $(C)$ and VIP $(D)$ mRNA by Northern blot analysis. Neuropeptide mRNA levels are expressed as ratios to the levels of GAPDH mRNA in each sample and represent the means of 12 DRG from two separate experiments. The data presented in Figure 9 using probes for other mRNAs were obtained from the same blots. ${ }^{*} p<0.04,{ }^{*} p<0.006$, and ${ }^{* * *} p<0.0001$ versus NSS at the same time point.
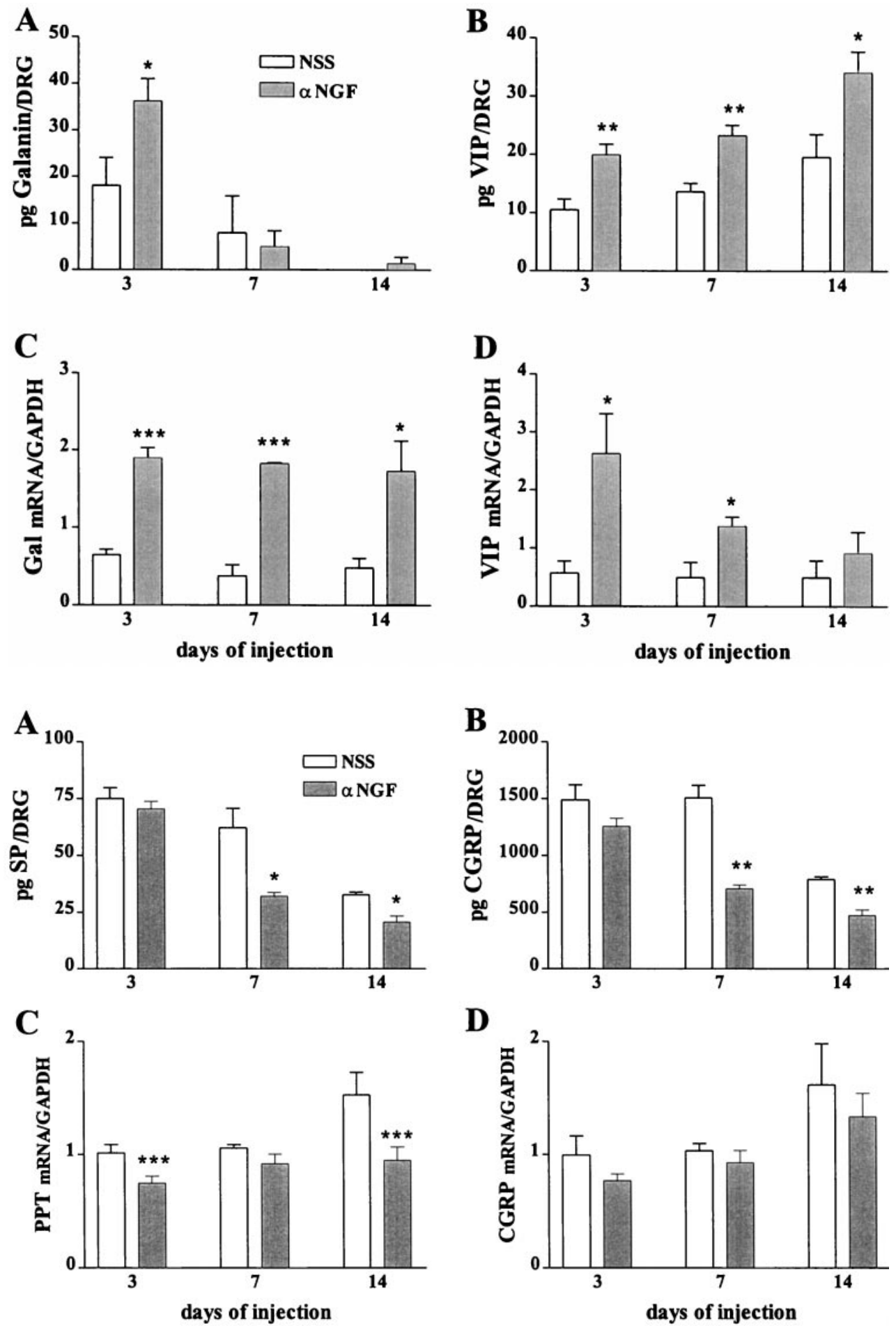

D

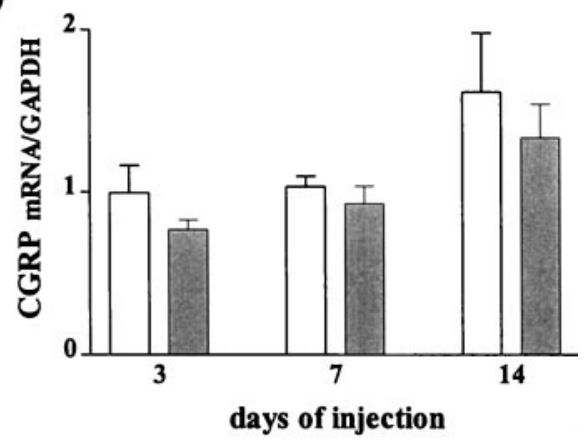

Curtis et al., 1994; Sun et al., 1994). Considerable evidence exists that LIF plays a large role in the switch in neuropeptide phenotype (Zigmond, 1997). The present study was designed to determine whether the reduction in NGF levels also may play a significant role.

The sensitivity of different neurons to particular neurotrophins depends on which neurotrophin receptors they express. All sympathetic neurons of the SCG express trkA, whereas only a small subpopulation expresses trkC and few, if any, express trkB (Wetmore and Olson, 1995; Bamji et al., 1998). Sensory neurons of the
DRG are more heterogeneous in their expression of neurotrophin receptors. TrkA expression is found primarily in the small neurons, trkC is present in large neurons, and trkB is found in both medium and small neurons (Wetmore and Olson, 1995; Wright and Snider, 1995).

Although sympathetic and certain sensory neurons are dependent on NGF for survival only during a distinct period in development (Angeletti et al., 1971; Bjerre et al., 1975; Johnson, 1983; Lindsay, 1988), NGF still produces phenotypic changes in adult neurons. For example, the lengths of dendrites in neurons in the 
adult SCG can be increased or decreased by increasing or decreasing the availability of NGF (Ruit et al., 1990). The expression of the low-affinity neurotrophin receptor (p75) can be increased by the administration of exogenous NGF (Miller et al., 1994) and decreased by the administration of $\alpha$ NGF (Zhou and Rush, 1996), whereas c-JUN expression responds in the opposite manner to alterations in NGF levels (Gold et al., 1993).

Because NGF principally reaches sympathetic and sensory neurons by retrograde transport from target tissues, NGF levels in the SCG decrease dramatically after axotomy (Nagata et al., 1987), after blockade of axonal transport with colchicine (Korsching and Thoenen, 1985a), and after destruction of sympathetic nerve terminals with 6-hydroxydopamine (Korsching and Thoenen, 1985a). These three manipulations also increase the levels of VIP and galanin mRNAs in this ganglion (Hyatt-Sachs et al., 1996; Zigmond et al., 1996). An additional way to reduce the level of NGF in sympathetic and sensory neurons is by injecting animals systemically with an antiserum raised against the neurotrophin (Zhou et al., 1994). Although the procedures discussed above block the retrograde transport of a large number of molecules, the antiserum approach is much more selective. A particular NGF antiserum, however, may not be totally specific for decreasing NGF levels (Murphy et al., 1993). For example, the antiserum used in this study inhibited the actions of both NGF and NT-3 in an in vitro bioassay, although BDNF was unaffected (Van der Zee et al., 1995). An effect of $\alpha$ NGF on NT-3, however, may not be a problem in the interpretation of our data at least in the SCG because the peptides that are decreased by $\alpha \mathrm{NGF}$, namely galanin and VIP, are not affected by NT-3 (see Fig. 1).

Decreasing NGF availability in nonoperated animals increases peptide and mRNA levels of both galanin and VIP in the SCG and DRG. Although, in principle, $\alpha$ NGF actually might alter neuropeptide expression by increasing LIF expression, no change in LIF mRNA was found in the SCG in animals that were given the antiserum (Shadiack et al., 1998). These data suggest that endogenous NGF inhibits galanin and VIP expression in these neurons in vivo, a possibility also consistent with the finding that exogenous NGF partially inhibits the increases in these peptides that normally are seen in the SCG after axotomy. In lumbar DRG, exogenous NGF also has been shown to inhibit both galanin and VIP expression in vivo (Verge et al., 1995) (although see also Ji et al., 1996) and galanin expression in vitro (Mulderry and Lindsay, 1990; Kerekes et al., 1997).

It is noteworthy that the extents of the increases in galanin-IR and VIP-IR in the SCG after the administration of $\alpha$ NGF are significantly smaller than after axotomy (cf. Hyatt-Sachs et al., 1993; Schreiber et al., 1994). Presumably, this difference results from the involvement of both LIF induction and NGF reduction in the regulation of these peptides after axotomy (Sun et al., 1994; Sun and Zigmond, 1996). Furthermore, in addition to the findings reported here that decreasing NGF availability in vivo, per se, can increase galanin expression, we recently have shown that decreasing NGF has a synergistic action on the galanin response of the SCG to LIF (Shadiack et al., 1998). Similar interactions between NGF and LIF in sympathetic and sensory ganglia have been suggested by other workers (Corness et al., 1998; Rajan et al., 1998).

\section{Decreased NGF is also a trigger for the decreases in expression of certain neuropeptides after axotomy}

In addition to increasing the expression of galanin, VIP, and substance $\mathrm{P}$ in the SCG, axotomy decreases the expression of
NPY, a normal constituent of many sympathetic neurons (Sun and Zigmond, 1996a). Interestingly, with regard to NPY, the change in expression is comparable in magnitude after axotomy and after antiserum treatment. In addition, LIF plays only a minor role in the regulation of NPY after axotomy (Sun and Zigmond, 1996a). Finally, exogenous NGF increases NPY expression in PC12 cells (Sabol and Higuchi, 1990; Higuchi et al., 1992). These data suggest that the decrease in NGF availability after axotomy is mainly responsible for the decrease in NPY expression.

$\alpha \mathrm{NGF}$ administration also produced decreases in the levels of two neuropeptides in intact DRG, namely, substance $\mathrm{P}$ and CGRP. This effect of $\alpha$ NGF on substance $\mathrm{P}$ is similar to that reported previously by Schwartz et al. (1982). In addition, studies with administration of exogenous NGF have demonstrated that the neurotrophin can increase substance P and CGRP expression in sensory neurons in vitro (Lindsay and Harmar, 1989; Lindsay et al., 1989; MacLean et al., 1989; Watson and Latchman, 1995) and in vivo (Wong and Oblinger, 1991; Amann et al., 1996). Finally, autoradiography with radioactive NGF and immunohistochemistry have indicated that a vast majority of the substance P- and CGRP-containing neurons express trkA, the high-affinity receptor for NGF (Verge et al., 1989; Kashiba et al., 1996).

In experiments on the effects of $\alpha \mathrm{NGF}$ in intact neurons described in the present study, neuropeptide expression was monitored both at the peptide and mRNA levels, and, in general, comparable changes were seen at both levels, except in the cases of SP and CGRP in DRG. The latter data raise the possibility that part of the effect of NGF on these peptides is at the posttranscriptional level. Precedence for the regulation of neuropeptide expression in peripheral neurons at the post-transcriptional level exists in the case of somatostatin (Spiegel et al., 1990).

\section{$\alpha$ NGF did not alter TH expression in the intact SCG}

TH activity and the level of TH mRNA decrease in sympathetic neurons after axotomy (Cheah and Geffen, 1973; Koo et al., 1988; Sun and Zigmond, 1996) or after colchicine treatment (Kessler and Black, 1979). These decreases in enzyme activity can be prevented (or reversed) by administration of exogenous NGF (Kessler and Black, 1979; Federoff et al., 1992). The trigger for the decrease in TH $m R N A$ after axotomy is not known. Studies with $\mathrm{LIF}^{-/-}$mice have indicated that LIF plays only a minor role in this decrease (Sun and Zigmond, 1996a), although the addition of exogenous LIF to cultured neonatal neurons decreases $\mathrm{TH}$ mRNA (Nawa et al., 1991), and the overexpression of LIF in vivo in animals that also overexpress NGF decreases TH-IR (Bamber et al., 1994). The finding that $\alpha$ NGF administration does not lead to a decrease in TH mRNA in intact SCG indicates that decreases in NGF availability that are large enough to affect the mRNA levels of a number of neuropeptides do not affect TH mRNA levels. This lack of effect of $\alpha$ NGF was unexpected, given the large number of studies showing that NGF treatment of cultured sympathetic neurons or PC12 cells increases the levels of $\mathrm{TH}$ mRNA (Raynaud et al., 1988; Toma et al., 1997) and of TH protein (Hefti et al., 1982).

\section{Overview}

Our data demonstrate that changes in NGF availability, in the absence of neural injury, trigger both increases and decreases of particular neuropeptides in sympathetic and sensory neurons. These results suggest that the decrease in NGF that occurs as a consequence of axotomy plays an important role in the axotomy- 
induced changes in these peptides. Previous studies have indicated that LIF also plays an important role in these changes (Rao et al., 1993a; Sun et al., 1994; Corness et al., 1996; Sun and Zigmond, 1996b). Recently, it has been found that the axotomyinduced decreases in the SCG of mRNAs for several nicotinic receptor subunits cannot be explained solely by changes in LIF and NGF availability, and we have postulated the involvement of additional factors (Zhou et al., 1998). The most conservative interpretation of our present findings with regard to the regulation of TH mRNA is also that a factor or factors, other than LIF and $\alpha \mathrm{NGF}$, play a major role in the decreased expression of $\mathrm{TH}$ mRNA after axotomy. Future studies will have to be directed at the identity of these regulatory molecules.

\section{REFERENCES}

Angeletti PU, Levi-Montalcini R, Caramia F (1971) Analysis of the effects of the antiserum to the nerve growth factor in adult mice. Brain Res 27:343-355

Amann R, Sirinathsinghji DJ, Donnerer J, Liebmann I, Schuligoi R (1996) Stimulation by nerve growth factor of neuropeptide synthesis in the adult rat in vivo: bilateral response to unilateral intraplantar injections. Neurosci Lett 203:171-174.

Amara SG, Arriza JL, Leff SE, Swanson LW, Evans RM, Rosenfeld MG (1985) Expression in brain of a messenger RNA encoding a novel neuropeptide homologous to calcitonin gene-related peptide. Science 229:1094-1097.

Bamber BA, Masters BA, Hoyle GW, Brinster RL, Palmiter RD (1994) Leukemia inhibitory factor induces neurotransmitter switching in transgenic mice. Proc Natl Acad Sci USA 91:7839-7843.

Bamji SX, Majdan M, Pozniak CD, Belliveau DJ, Aloyz R, Kohn J, Causing CG, Miller FD (1998) The p75 neurotrophin receptor mediates neuronal apoptosis and is essential for naturally occurring sympathetic neuron death. J Cell Biol 140:911-923.

Banner LR, Patterson PH (1994) Major changes in the expression of the mRNAs for cholinergic differentiation factor/leukemia inhibitory factor and its receptor after injury to adult peripheral nerves and ganglia. Proc Natl Acad Sci USA 91:7109-7113.

Bjerre B, Wiklund L, Edwards DC (1975) A study of the de- and regenerative changes in the sympathetic nervous system of the adult mouse after treatment with the antiserum to nerve growth factor. Brain Res 92:257-278.

Cheah TB, Geffen LB (1973) Effects of axonal injury on norepinephrine tyrosine hydroxylase, and monoamine oxidase levels in sympathetic ganglia. J Neurobiol 4:443-452.

Corness J, Shi TJ, Xu ZQ, Brulet P, Hökfelt T (1996) Influence of leukemia inhibitory factor on galanin/GMAP and neuropeptide Y expression in mouse primary sensory neurons after axotomy. Exp Brain Res 112:79-88.

Corness J, Stevens B, Fields RD, Hökfelt T (1998) NGF and LIF both regulate galanin gene expression in primary DRG cultures. NeuroReport 9:1533-1536

Curtis R, Scherer SS, Somogyi R, Adryan KM, Ip NY, Zhu Y, Lindsay RM, Di Stefano PS (1994) Retrograde axonal transport of LIF is increased by peripheral nerve injury: correlation with increased LIF expression in distal nerve. Neuron 12:191-204.

Federoff HJ, Geschwind MD, Geller AI, Kessler JA (1992) Expression of nerve growth factor in vivo from a defective herpes simplex virus 1 vector prevents effects of axotomy on sympathetic ganglia. Proc Natl Acad Sci USA 89:1636-1640.

Fort P, Marty L, Piechaczyk M, el Sabrouty S, Dani C, Jeanteur P, Blanchard JM (1985) Various rat adult tissues express only one major mRNA species from the glyceraldehyde-3-phosphate-dehydrogenase multigenic family. Nucleic Acids Res 13:1431-1442.

Gloster A, Diamond J (1995) NGF-dependent and NGF-independent recovery of sympathetic function after chemical sympathectomy with 6-hydroxydopamine. J Comp Neurol 359:4 586-594.

Gold BG, Storm-Dickerson T, Austin DR (1993) Regulation of the transcription factor c-JUN by nerve growth factor in adult sensory neurons. Neurosci Lett 154:129-133.

Grima B, Lamouroux A, Blanot F, Biguet NF, Mallet J (1985) Complete coding sequence of rat tyrosine hydroxylase mRNA. Proc Natl Acad Sci USA 82:617-621.

Hårkönen M (1964) Carboxylic esterases, oxidative enzymes, and catecholamines in the superior cervical ganglion of the rat and the effect of pre- and postganglionic nerve division. Acta Physiol Scand Suppl 63 [Suppl 237]:1-94.

Harrington CA, Lewis EJ, Krzemien D, Chikaraishi DM (1987) Identification and cell-type specificity of the tyrosine hydroxylase gene promoter. Nucleic Acids Res 15:2363-2384.
Hebb C, Silver A (1966) Axoplasmic flow of protein. In: Protides of the biological fluids (Peeters H, ed), pp 179-180. Amsterdam: Elsevier.

Hefti F, Gnahn H, Schwab ME, Thoenen H (1982) Induction of tyrosine hydroxylase by nerve growth factor and by elevated $\mathrm{K}^{+}$concentrations in cultures of dissociated sympathetic neurons. J Neurosci 2:1554-1566.

Hendry IA (1976) Effects of axotomy on the trans-synaptic regulation of enzyme activity in adult rat superior cervical ganglia. Brain Res 107:105-116.

Higuchi H, Yang HY, Sabol SL (1988) Rat neuropeptide Y precursor gene expression: mRNA structure, tissue distribution, and regulation by glucocorticoids, cyclic AMP, and phorbol ester. J Biol Chem 263:6288-6295.

Higuchi H, Nakano K, Miki N (1992) Identification of NGF-response element in the rat neuropeptide $\mathrm{Y}$ gene and induction of the binding proteins. Biochem Biophys Res Commun 189:1553-1560.

Holmes FE, McMahon SB, Murphy D, Wynick D (1997) Targeted disruption of galanin reduces nerve regeneration and neuropathic pain. Soc Neurosci Abstr 23:1954.

Hyatt-Sachs H, Schreiber RC, Bennett TA, Zigmond RE (1993) Phenotypic plasticity in adult sympathetic ganglia in vivo: effects of deafferentation and axotomy on the expression of vasoactive intestinal peptide. J Neurosci 13:1642-1653.

Hyatt-Sachs H, Bachoo M, Schreiber R, Vaccariello SA, Zigmond RE (1996) Chemical sympathectomy and postganglionic nerve transection similarly increase galanin and VIP mRNA, but not the peptides themselves. J Neurobiol 30:543-555.

Ji RR, Zhang Q, Pettersson RF, Hökfelt T (1996) aFGF, bFGF, and NGF differentially regulate neuropeptide expression in dorsal root ganglia after axotomy and induce autotomy. Regul Pept 66:179-189.

Johnson M I (1983) Dissociated neurons from adult rat superior cervical ganglion show reduced NGF requirements in culture. Soc Neurosci Abstr 9:846.

Kashiba H, Ueda Y, Senba E (1996) Coexpression of preprotachykinin-A, $\alpha$-calcitonin gene-related peptide, somatostatin, and neurotrophin receptor family messenger RNAs in rat dorsal root ganglion neurons. Neuroscience 70:179-189.

Kerekes N, Landry M, Rydh-Rinder M, Hökfelt T (1997) The effect of NGF, BDNF, and bFGF on expression of galanin in cultured rat dorsal root ganglia. Brain Res 754:131-141.

Kessler JA, Black IB (1979) The role of axonal transport in the regulation of enzyme activity in sympathetic ganglia of adult rats. Brain Res 171:415-424.

Klimaschewski L, Unsicker K, Heym C (1995) Vasoactive intestinal peptide but not galanin promotes survival of neonatal rat sympathetic neurons and neurite outgrowth of PC12 cells. Neurosci Lett 195:133-136.

Koo EH, Hoffman PN, Price DL (1988) Levels of neurotransmitter and cytoskeletal protein mRNAs during nerve regeneration in sympathetic ganglia. Brain Res 449:361-363.

Korsching S, Thoenen H (1985a) Treatment with 6-hydroxydopamine and colchicine decreases nerve growth factor levels in sympathetic ganglia and increases them in the corresponding target tissues. J Neurosci 5:1058-1061.

Korsching S, Thoenen H (1985b) Nerve growth factor supply for sensory neurons: site of origin and competition with the sympathetic nervous system. Neurosci Lett 54:201-205.

Krause JE, Chirgwin JM, Carter MS, Xu ZS, Hershey AD (1987) Three rat preprotachykinin mRNAs encode the neuropeptides substance $\mathrm{P}$ and neurokinin A. Proc Natl Acad Sci USA 84:881-885.

Kroesen S, Lang S, Fischer-Colbrie R, Klimaschewski L (1997) Plasticity of neuropeptide $\mathrm{Y}$ in the rat superior cervical ganglion in response to nerve lesion. Neuroscience 78:251-258.

Liabotis S, Schreyer DJ (1995) Magnitude of GAP-43 induction following peripheral axotomy of adult rat dorsal root ganglion neurons is independent of lesion distance. Exp Neurol 135:28-35.

Lindsay RM (1988) Nerve growth factors (NGF, BDNF) enhance axonal regeneration but are not required for survival of adult sensory neurons. J Neurosci 8:2394-2405.

Lindsay RM, Harmar AJ (1989) Nerve growth factor regulates expression of neuropeptide genes in adult sensory neurons. Nature 337:362-364

Lindsay RM, Lockett C, Sternberg J, Winter J (1989) Neuropeptide expression in cultures of adult sensory neurons: modulation of substance $\mathrm{P}$ and calcitonin gene-related peptide levels by nerve growth factor. Neuroscience 33:53-65.

MacLean DB, Bennett B, Morris M, Wheeler FB (1989) Differential regulation of calcitonin gene-related peptide and substance $\mathrm{P}$ in cultured neonatal rat vagal sensory neurons. Brain Res 478:349-355.

Mathew TC, Miller FD (1990) Increased expression of T $\alpha 1 \alpha$-tubulin mRNA during collateral and NGF-induced sprouting of sympathetic neurons. Dev Biol 141:84-92.

Miller FD, Speelman A, Mathew TC, Fabian J, Chang E, Pozniak C, Toma JG (1994) Nerve growth factor derived from terminals selectively increases the ratio of p75 to trkA NGF receptors on mature sympathetic neurons. Dev Biol 161:206-217. 
Mulderry PK, Lindsay RM (1990) Rat dorsal root ganglion neurons in culture express vasoactive intestinal polypeptide (VIP) independently of nerve growth factor. Neurosci Lett 108:314-320.

Murphy RA, Acheson A, Hodges R, Haskins J, Richards C, Reklow E, Chlumecky V, Barker PA, Alderson RF, Lindsay RM (1993) Immunological relationships of NGF, BDNF, and NT-3: recognition and functional inhibition by antibodies to NGF. J Neurosci 13:2853-2862.

Nagata Y, Ando M, Takahama K, Iwata M, Hori S, Kato K (1987) Retrograde transport of endogenous nerve growth factor in superior cervical ganglion of adult rats. J Neurochem 49:296-302.

Nawa H, Nakanishi S, Patterson P (1991) Recombinant cholinergic differentiation factor (leukemia inhibitory factor) regulates sympathetic neuron phenotype by alterations in the size and amounts of neuropeptide mRNAs. J Neurochem 56:2147-2150.

Rajan P, Gearan T, Fink JS (1998) Leukemia inhibitory factor and NGF regulate signal transducers and activators of transcription activation in sympathetic ganglia: convergence of cytokine- and neurotrophinsignaling pathways. Brain Res 802:198-204.

Rao MS, Sun Y, Escary JL, Perreau J, Patterson PH, Zigmond RE, Brulet P, Landis SC (1993a) Leukemia inhibitory factor mediates an injury response but not a developmental transmitter switch in sympathetic neurons. Neuron 11:1175-1185.

Rao MS, Sun Y, Vaidyanathan U, Landis SC, Zigmond RE (1993b) Regulation of substance $\mathrm{P}$ is similar to that of vasoactive intestinal peptide after axotomy or explantation of the rat superior cervical ganglion. J Neurobiol 24:571-580.

Rayan GM, Johnson C, Pitha J, Cahill S, Said S (1995) Vasoactive intestinal peptide and nerve growth factor effects on nerve regeneration. J Okla State Med Assoc 88:337-341.

Raynaud B, Faucon-Biguet N, Vidal S, Mallet J, Weber MJ (1988) Regulation of neurotransmitter metabolic enzymes and tyrosine hydroxylase mRNA level by nerve growth factor in cultured sympathetic neurones. Development 102:361-368.

Ruit KG, Osborne PA, Schmidt RE, Johnson Jr EM, Snider WD (1990) Nerve growth factor regulates sympathetic ganglion cell morphology and survival in the adult mouse. J Neurosci 10:2412-2419.

Sabol SL, Higuchi H (1990) Transcriptional regulation of the neuropeptide Y gene by nerve growth factor: antagonism by glucocorticoids and potentiation by adenosine $3^{\prime}, 5^{\prime}$-monophosphate and phorbol ester. Mol Endocrinol 4:384-392.

Schreiber RC, Hyatt-Sachs H, Bennett TA, Zigmond RE (1994) Galanin expression increases in adult rat sympathetic neurons after axotomy. Neuroscience 60:17-27.

Schwartz JP, Pearson J, Johnson EM (1982) Effect of exposure to antiNGF on sensory neurons of adult rats and guinea pigs. Brain Res 244:378-381.

Segerson TP, Lam KS, Cacicedo L, Minamitani N, Fink JS, Lechan RM, Reichlin S (1989) Thyroid hormone regulates vasoactive intestinal peptide (VIP) mRNA levels in the rat anterior pituitary gland. Endocrinology 125:2221-2223.

Shadiack AM, Vaccariello SA, Sun Y, Zigmond RE (1998) Nerve growth factor inhibits sympathetic neurons' response to an injury cytokine. Proc Natl Acad Sci USA 95:7727-7730.

Spiegel K, Wong V, Kessler JA (1990) Translational regulation of somatostatin in cultured sympathetic neurons. Neuron 4:303-311.

Sun Y, Zigmond RE (1995) Differential effects of long-term and shortterm NGF treatment on neuropeptide expression in axotomized superior cervical ganglia (SCG) in vivo. Soc Neurosci Abstr 21:1052.

Sun Y, Zigmond RE (1996a) Involvement of leukemia inhibitory factor in the increases in galanin and vasoactive intestinal peptide mRNA and the decreases in neuropeptide $\mathrm{Y}$ and tyrosine hydroxylase mRNA after axotomy of sympathetic neurons. J Neurochem 67:1751-1760.

Sun Y, Zigmond RE (1996b) Leukemia inhibitory factor induced in the sciatic nerve after axotomy is involved in the induction of galanin in sensory neurons. Eur J Neurosci 8:2213-2220.

Sun Y, Rao M, Landis S, Zigmond RE (1992) Depolarization increases vasoactive intestinal peptide and substance P-like immunoreactivities in neonatal and adult sympathetic neurons. J Neurosci 12:3717-3728.
Sun Y, Shadiack AM, Landis SC, Zigmond RE (1993) Differential effects of cholinergic differentiation factor/leukemia inhibitory factor $(\mathrm{CDF} / \mathrm{LIF})$ and $\mathrm{NGF}$ on peptide expression in adult rat superior cervical ganglion (SCG). Soc Neurosci Abstr 19:664.

Sun Y, Rao MS, Zigmond RE, Landis SC (1994) Regulation of vasoactive intestinal peptide expression in sympathetic neurons in culture and after axotomy: the role of cholinergic differentiation factor/leukemia inhibitory factor. J Neurobiol 25:415-430.

Sun Y, Landis SC, Zigmond RE (1996) Signals triggering the induction of leukemia inhibitory factor in sympathetic superior cervical ganglia and their nerve trunks after axonal injury. Mol Cell Neurosci 7:152-163.

Tanaka S, Koike T (1994) Vasoactive intestinal peptide suppresses neuronal cell death induced by nerve growth factor deprivation in rat sympathetic ganglion cells in vitro. Neuropeptides 26:103-111.

Toma JG, Rogers D, Senger DL, Campenot RB, Miller FD (1997) Spatial regulation of neuronal gene expression in response to nerve growth factor. Dev Biol 184:1-9.

Van der Zee CE, Rashid K, Le K, Moore KA, Stanisz J, Diamond J, Racine RJ, Fahnestock M (1995) Intraventricular administration of antibodies to nerve growth factor retards kindling and blocks mossy fiber sprouting in adult rats. J Neurosci 15:5316-5323.

Verge VM, Richardson PM, Benoit R, Riopelle RJ (1989) Histochemical characterization of sensory neurons with high-affinity receptors for nerve growth factor. J Neurocytol 18:583-591.

Verge VMK, Richardson PM, Wiesenfeld-Hallin Z, Hökfelt T (1995) Differential influence of nerve growth factor on neuropeptide expression in vivo: a novel role in peptide suppression in adult sensory neurons. J Neurosci 15:2081-2096.

Watson A, Latchman D (1995) The cyclic AMP response element in the calcitonin/calcitonin gene-related peptide gene promoter is necessary but not sufficient for its activation by nerve growth factor. J Biol Chem 270:9655-9660.

Wetmore C, Olson L (1995) Neuronal and non-neuronal expression of neurotrophins and their receptors in sensory and sympathetic ganglia suggest new intercellular trophic interactions. J Comp Neurol 353:143-159.

Wong J, Oblinger MM (1991) NGF rescues substance P expression but not neurofilament or tubulin gene expression in axotomized sensory neurons. J Neurosci 11:543-552.

Wright DE, Snider WD (1995) Neurotrophin receptor mRNA expression defines distinct populations of neurons in rat dorsal root ganglia. J Comp Neurol 351:329-338.

Zhou HF, Rush RA (1996) Endogenous nerve growth factor is required for regulation of the low affinity neurotrophin receptor (p75) in sympathetic but not sensory ganglia. J Comp Neurol 372:37-48.

Zhou X-F, Zettler C, Rush RA (1994) An improved procedure for the immunohistochemical localization of nerve growth factor-like immunoreactivity. J Neurosci Methods 54:95-102.

Zhou Y, Deneris E, Zigmond RE (1998) Differential regulation of levels of nicotinic receptor subunit transcripts in adult sympathetic neurons after axotomy. J Neurobiol 34:164-178.

Zigmond RE (1997) LIF, NGF, and the cell body response to axotomy. The Neuroscientist 3:176-185.

Zigmond RE, Hyatt-Sachs H, Baldwin C, Qu XM, Sun Y, McKeon TW, Schreiber RC, Vaidyanathan U (1992) Phenotypic plasticity in adult sympathetic neurons: changes in neuropeptide expression in organ culture. Proc Natl Acad Sci USA 89:1507-1511.

Zigmond RE, Shadiack AM, Sun Y (1995) Antiserum to nerve growth factor (NGF) alters neuropeptide expression in the superior cervical ganglion (SCG) and dorsal root ganglion (DRG) in vivo. Soc Neurosci Abstr 21:1052.

Zigmond RE, Hyatt-Sachs H, Mohney RP, Schreiber RC, Shadiack AM, Sun Y, Vaccariello SA (1996) Changes in neuropeptide phenotype after axotomy of adult peripheral neurons and the role of leukemia inhibitory factor. Perspect Dev Neurobiol 4:75-90. 